\title{
Land Cover Controls the Export of Terminal Electron Acceptors from Boreal Catchments
}

\author{
Marjo Palviainen, ${ }^{1 *}$ Jouni Lehtoranta, ${ }^{2}$ Petri Ekholm, ${ }^{2}$ Tuija Ruoho-Airola, ${ }^{3}$ \\ and Pirkko Kortelainen ${ }^{2}$
}

${ }^{1}$ Department of Forest Sciences, University of Helsinki, P.O. Box 27, 00014 Helsinki, Finland; ${ }^{2}$ Finnish Environment Institute (SYKE), P.O. Box 140, 00251 Helsinki, Finland; ${ }^{3}$ Finnish Meteorological Institute, P.O. Box 503, 00101 Helsinki, Finland

\begin{abstract}
$\mathrm{NO}_{3}, \mathrm{Mn}, \mathrm{Fe}$, and $\mathrm{SO}_{4}$ act as terminal electron acceptors (TEAs), modifying mineralization pathways and coupling biogeochemical cycles. Although single TEA concentrations and fluxes have been intensively studied, the factors regulating the simultaneous fluxes and molar ratios of TEAs are poorly elucidated. We studied the mean concentrations, exports, and molar ratios of TEAs from 27 boreal catchments differing in land cover (percentage of agricultural land, peatland, forest, and built-up area) during the years 2000-2011. TEA exports and molar ratios were strongly controlled by land cover and only a little by atmospheric deposition. Fields produced the highest export of TEAs, particularly $\mathrm{NO}_{3}$. Peatland was linked to low $\mathrm{NO}_{3}$ and $\mathrm{SO}_{4}$, but high Fe exports. $\mathrm{NO}_{3}, \mathrm{Mn}$, and $\mathrm{Fe}$
\end{abstract}

exports from forests were low, $\mathrm{SO}_{4}$ having proportionally the highest export. Together, the percentages of field and peatland predicted 93, 80, 75, and $67 \%$ of the variation in the export of $\mathrm{NO}_{3}, \mathrm{Mn}$, $\mathrm{Fe}$, and $\mathrm{SO}_{4}$, respectively. The variable export of TEAs having different availability and physical behavior may create different premises for anaerobic mineralization in downstream systems, which adds a new dimension to the link between terrestrial system, land use, and environmental problems, such as eutrophication and climate change.

Key words: atmospheric deposition; climate change; eutrophication; iron; land cover; manganese; nitrate; organic carbon; sulfate.

\section{INTRODUCTION}

Only linking the ecological status of surface waters to the load of nutrients and organic $\mathrm{C}$ may prove to be too narrow a perspective toward understanding and managing aquatic ecosystems. The export of terrestrial organic $\mathrm{C}$ and primary production

Received 7 July 2014; accepted 12 November 2014 published online 23 December 2014

Author contributions Jouni Lehtoranta, Petri Ekholm, and Pirkko Kortelainen designed the study. Tuija Ruoho-Airola provided atmospheric deposition data. Marjo Palviainen analyzed the data and wrote the paper, with substantial contributions from all co-authors.

*Corresponding author; e-mail: marjo.palviainen@helsinki.fi determine the potential for mineralization in a body of water. Microbial redox reactions consuming terminal electron acceptors (TEAs) are central in mineralization processes. TEAs include a set of common compounds, for example, $\mathrm{O}_{2}, \mathrm{NO}_{3}, \mathrm{Mn}$ and $\mathrm{Fe}$ oxides, and $\mathrm{SO}_{4}$. Through the primary and secondary redox reactions, TEAs contribute to (i) the availability of nutrients (Rysgaard and others 2001; Smolders and others 2006, 2010; Lehtoranta and others 2009; Burgin and others 2011; Hall and Silver 2013), (ii) the fluxes of greenhouse gases (Conrad 1996; Dise and Verry 2001; Davidson and Seitzinger 2006; Raghoebarsing and others 2006; Beal and others 2009; Knittel and Boetius 
2009; Cai and others 2012; Bridgham and others 2013; Kortelainen and others 2013), and (iii) the mobilization of harmful substances (Islam and others 2004; Burgin and others 2011). For example, a generation of toxic sulfides (Wang and Chapman 1999) may block Fe cycling and enhance the release of $\mathrm{P}$ from bottom sediments into water (Smolders and others 2006, 2010; Lehtoranta and others 2009). Therefore, the ecological status of an aquatic system is also a function of TEAs, as they partly control mineralization processes and pathways. Yet, the fluxes of TEAs and the factors regulating them at the catchment level have remained poorly quantified.

Depending on the availability of organic $\mathrm{C}$ and TEAs, and the morphological features of the system, TEAs and their end products may escape an aquatic system (i) untouched, (ii) in a more reduced or oxidized, yet dissolved form, (iii) in a gaseous form $\left(\mathrm{N}_{2}, \mathrm{~N}_{2} \mathrm{O}, \mathrm{H}_{2} \mathrm{~S}\right)$ after the reduction process, or (iv) through burial of solid compounds $(\mathrm{N}, \mathrm{Mn}, \mathrm{Fe}, \mathrm{S})$ in bottom sediments. Owing to such losses, an external source of TEAs or their precursors is needed to maintain TEA concentrations in the system, although endogenous oxidation processes may sustain a specific mineralization pathway in surface sediments for significant periods (that is, reductive and oxidative cycles of Fe or S; Urban and others 1994; Holmer and Storkholm 2001; Thomsen and others 2004).

Atmosphere, soil, and bedrock form the primary sources of TEAs, while land cover may markedly modify the TEA export from the catchment into aquatic systems (Figure 1). In agricultural fields, fertilization increases the fluxes of $\mathrm{NO}_{3}$ and $\mathrm{SO}_{4}$ (Korkman 1973; Mattsson and others 2007) and tillage those of $\mathrm{Fe}$ oxides by accelerating soil erosion (Ekholm and Lehtoranta 2012). In peatland,

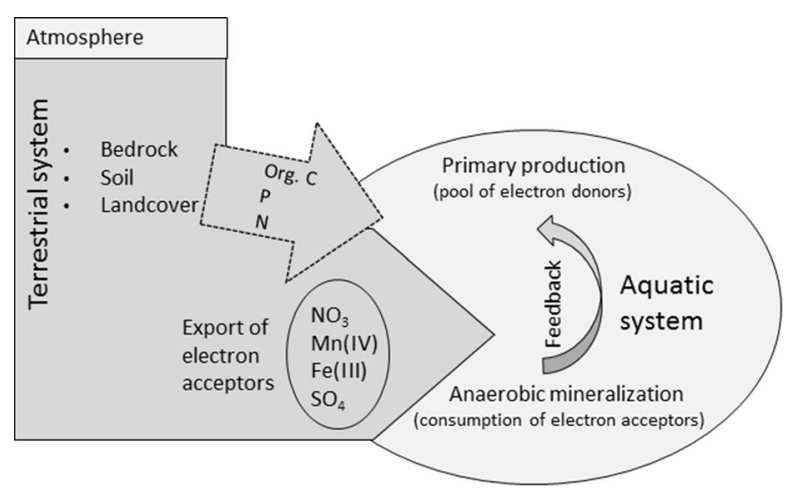

Figure 1. Factors controlling the export of major electron acceptors from terrestrial systems affecting mineralization and the coupling of element cycles in aquatic systems. the export of TEAs may be governed by the peat itself and by soil underneath through anaerobic microbial redox processes, driven by natural or man-made fluctuation of the water level (Martikainen and others 1993; Regina and others 1996; Mörth and others 1999; Eimers and others 2004; Kane and others 2013). In contrast to water-logged peatland, the prevailing oxic conditions in forests may maintain the ability of soil to retain TEAs (MacDonald and others 2002; Fuss and others 2011). $\mathrm{NO}_{3}$ may also be retained through the assimilation of biota to long-term organic pools, which reduces the flux of $\mathrm{NO}_{3}$ from boreal forests (Tamm 1991; Kortelainen and others 2006). In addition to land cover, atmospheric deposition may be an important driver affecting TEA export (Dise and Wright 1995; Gundersen and others 2006; Mattsson and others 2007), but the separate and mutual importance of these two factors regulating TEA export is largely unknown in boreal catchments. Moreover, most of the studies on TEAs have not recognized the inherent connection of TEAs, but have looked at specific TEAs separately from the viewpoint of acidification, erosion, eutrophication, and pollution (Henriksen and others 1992; Curtis and others 2005; Lehtoranta and others 2009; Ekholm and Lehtoranta 2012; Kopácek and others 2013).

The objective of this study was to investigate the export and molar share of TEAs $\left(\mathrm{NO}_{3}, \mathrm{Mn}, \mathrm{Fe}\right.$, and $\mathrm{SO}_{4}$ ) and how they vary in relation to the catchment land cover. To this aim, we examined numerous boreal catchments differing in land cover, hypothesizing that land cover and atmospheric deposition control the average annual export and the molar proportion of TEAs from the catchments.

\section{Materials ANd Methods}

\section{Study Areas}

The analysis was made for 27 catchments differing in land cover (Figure 2; Table 1). The catchments were located all over boreal Finland, between latitudes 60 and $68^{\circ} \mathrm{N}$, and their areas ranged from 0.1 to $4,283 \mathrm{~km}^{2}$. Land cover was divided into five percentual classes: peatland (open and forested peatlands, Peat \%), forests on mineral soils (Forest $\%$ ), agricultural fields (Field\%), built-up areas (Built-up\%), and water (Water\%). The land-cover data were derived from the national CORINE landcover (CLC2006) database $(25 \times 25$ m grids), except for Field $\%$ and Built-up $\%$. In the national CORINE database, Peat $\%$ was based on the topographical 


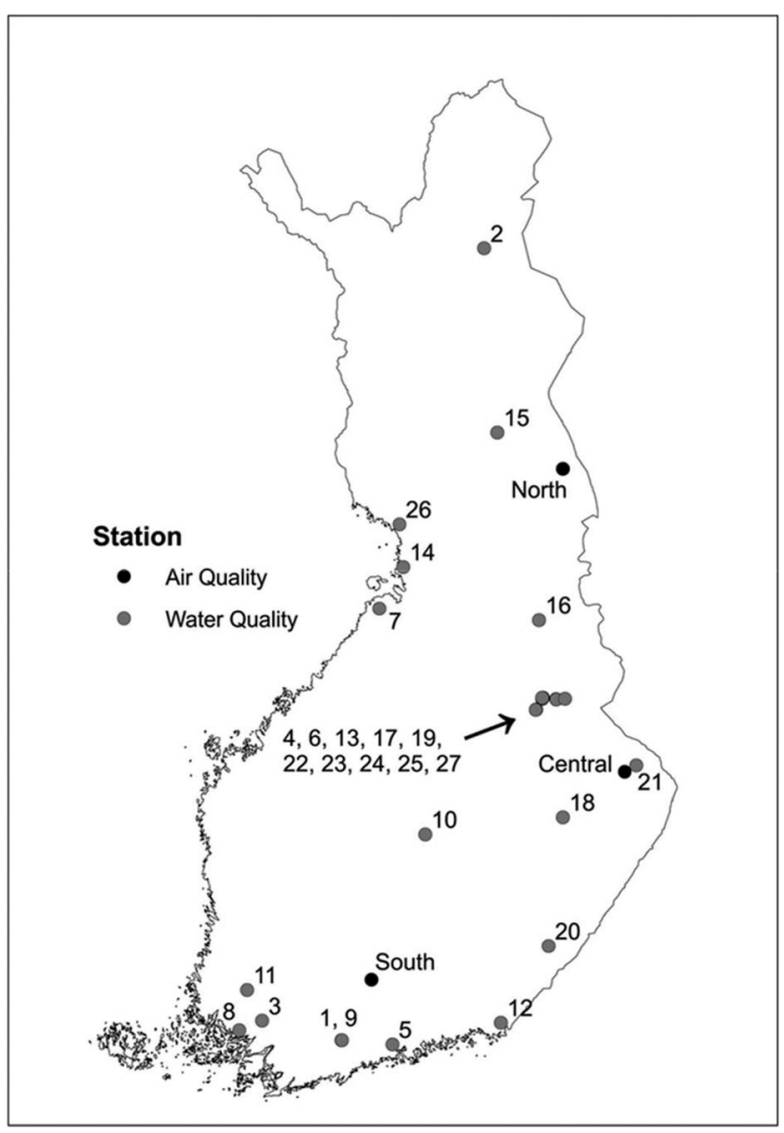

database of the National Land Survey of Finland. Peat $\%$ includes areas in which peatland vegetation dominates and the thickness of the peat layer is at least $30 \mathrm{~cm}$. Field \% was obtained from the field plot register owned by Mavi (Agency for Rural Affairs), in which all the field plots receiving area-based subsidies in 2010 were digitized. Built-up\% was derived from the Urban layer database $(25 \times 25 \mathrm{~m}$ grids) of the Finnish Environment Institute. Landcover data for small forested catchments $(4,6,13$, $17,19,22,23,24,25,27)$ were derived from field inventories.

Forest $\%$ ranged from 30 to 92 (average 62, Table 1) and was dominated by coniferous species, mainly Norway spruce (Picea abies Karsten) and Scots pine (Pinus sylvestris L.). Field\% varied between 0 and 42 (average 6.7) and Peat \% between 0 and 70 (average 28). Water areas, mainly small lakes, covered only $0-4 \%$ (average $1 \%$ ) of the catchments. Built-up\% included paved surfaces, such as urban or industrial areas, road networks, and aggregate extraction sites, and accounted for 0-6.9 (average 1.3). All the catchments were sparsely populated and point-source loading was negligible. Thus, the main human impacts in these catchments were due to agriculture, forestry, and
Figure 2. Location of the catchments and atmospheric deposition stations.
1 Yli-Knuuttila

2 Laanioja

3 Paimionjoki

4 Kangasvaara

5 Mustijoki

6 Kangaslampi

7 Siikajoki

8 Aurajoki

9 Teeressuonoja

10 Ruunapuro

11 Yläneenjoki

12 Virojoki

13 Porkkavaara

14 Kiiminkijoki

15 Vähä-Askanjoki

16 Myllypuro

17 Kivipuro

18 Kesselinpuro

19 Koivupuro

20 Huhtisuonoja

21 Kelopuro

22 Liuhapuro

23 Murtopuro

24 Korsukorpi

25 Välipuro

26 Kuivajoki

27 Suopuro

Atmospheric deposition stations

South (Kotinen)

Central (Hietajärvi)

North (Kuusamo) atmospheric deposition. The forestry practices, when present, consisted of thinning, clear-cutting, ditching, and/or soil scarification. Three catchments (22 Liuhapuro, 25 Välipuro, and 13 Porkkavaara) represented natural-state forests, where no forestry operations had been carried out during recent decades. Agricultural practices consisted of cereal crop and grass cultivation, with some poultry, pig, and cattle animal husbandry.

Bedrock was formed of granitic rocks, migmatites, and schists. Till and fine late-glacial minerogenic sediment covered the bedrock. Extensive fine-sediment deposits were mainly found in southern and western Finland. The soils in forested areas were Podzols or Dystric and Eutric Histosols. The soils not covered by forest were Leptosols, Cambisols, and Gleysols. The mean annual temperature was about $6^{\circ} \mathrm{C}$ in the southernmost catchments and about $0^{\circ} \mathrm{C}$ in the northernmost catchments. The mean annual precipitation ranged from 400 to $700 \mathrm{~mm}$ and the mean annual runoff from 203 to $440 \mathrm{~mm}$ during the study period (Table 1). The catchments have been described in more detail by Seuna (1983), Finér and others (1997), Vuorenmaa and others (2002), and Kortelainen and others (2006). 


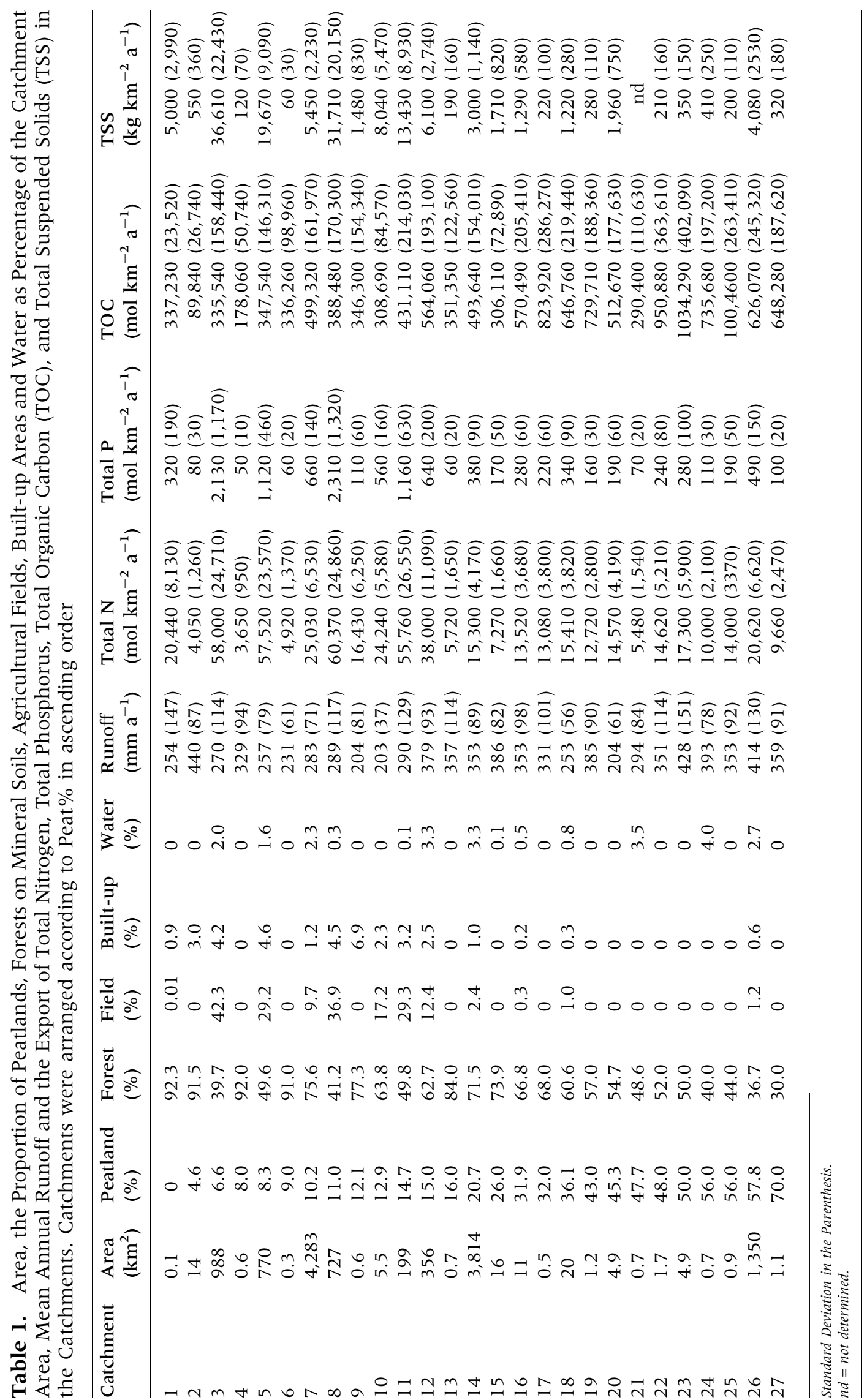




\section{Sampling and Determinations}

The study period covered the years 2000-2011. Daily runoff from the catchments was monitored for, predominantly, 11 or 12 years, except Yli-Knuuttila (1), where the runoff data was only available for 4 years. Daily runoff was determined by the rating curve method, using continuous water level data, or in the case of some rivers, from data obtained from hydropower plants. Water samples were taken, on average, 9-41 times per year, concentrating on spring and autumn high-flow periods (Table 2). The samples were analyzed with accredited methods in the laboratories of Regional Environment Centres and the Finnish Environment Institute. $\mathrm{NO}_{3}$ was analyzed by the $\mathrm{Cd}$ method and $\mathrm{SO}_{4}$ by ion-chromatography. Concentrations of total Fe, total Mn, total N, and total $\mathrm{P}$ were determined colorimetrically after digestion with $\mathrm{K}_{2} \mathrm{~S}_{2} \mathrm{O}_{8}$ in an autoclave. The digestion transforms analyte to a reactive form, oxidizes organic matter, and reduces inferring color, but may not attack all element forms, for example, those strongly bound in mineral particles. In Fe and Mn determinations, digestion is performed at low $\mathrm{pH}$ to form reactive forms of $\mathrm{Fe}$ and $\mathrm{Mn}$. Fe(III) is reduced to $\mathrm{Fe}(\mathrm{II})$ by hydroxylammonium chloride, and $\mathrm{Fe}(\mathrm{II})$ is stained by TPTZ. Mn(II) is stained by formaldoxime. According to a validation performed on natural waters by the Finnish Environment Institute, the total Fe determined with the above method differed less than $10 \%$ from total Fe determined with ICP-OES after digestion with nitric acid in a microwave oven. However, the colorimetrically analyzed total Mn gave somewhat higher and more variable results than ICPOES, which may indicate that the Mn values are overestimates. In our catchments, Fe and Mn have probably been in various chemical and physical forms, such as attached to inorganic particles in agricultural runoff and to organic colloids in humic waters. In such a setting, total concentrations include a variable fraction of bioavailable forms. The concentrations of total suspended solids (TSS) were determined as the portion retained on the $0.4 \mu \mathrm{m}$ polycarbonate or glass fiber filter. TOC concentrations were determined using high-temperature oxidation followed by infrared gas measurements. We excluded $\mathrm{O}_{2}$, as its supply is determined by water-air interactions, rather than land cover or atmospheric deposition.

The annual $\mathrm{SO}_{4}, \mathrm{NO}_{3}, \mathrm{Fe}$, and Mn bulk deposition values for southern, central, and northern Finland were derived from three deposition stations (Kotinen, Hietajärvi, and Kuusamo, Figure 2) run by the Finnish Meteorological Institute. The bulk deposition was measured continuously, using weekly or monthly sampling, according to the
EMEP manual (EMEP 2001). The samples were analyzed with accredited methods in the laboratory of the Finnish Meteorological Institute.

\section{Calculations and Statistical Analyses}

Daily concentrations for non-sampled days were linearly interpolated from sequential determined values. The daily loads were calculated by multiplying daily concentrations with daily runoff and annual exports were obtained by summing up the daily values. The limited frequency of the sampling and interpolation of concentrations may cause uncertainties in the calculated exports. The estimated exports may differ from the true exports, as the concentrations do not change linearly over time and there can be a short-term variation in water quality related to flow paths, transit times and discharge, and temporal variability in the biological activity (Barco and others 2013). In our study, the sampling frequency was higher during the high-flow periods in spring and autumn, which improved the accuracy of the element export estimates (Rekolainen and others 1991). To estimate the reliability of the linear interpolation method, annual exports were also estimated, using flow-weighted mean concentrations for a few catchments and the results given by these two methods were at the same level.

The relationship between land-use patterns and the export of TEAs was examined with principal component analysis (PCA) and multiple regression analysis. The five land-cover classes (field, built-up area, forest, peatland, and water) were used as predictors of mean annual concentrations and exports of TEAs. In the regression analysis, we entered the landcover classes one by one in the model, built separately for each TEA, and then selected the models on the basis of explanation power and mutual correlation between the explaining variables, excluding models with a variance inflation factor exceeding five. The regression models were validated using an independent dataset: catchments were arranged, according to Peat $\%$ in ascending order and every second, that is, 14 catchments were included in the model and the remaining 13 catchments were used in the model validation. The statistical analyses were performed with CANOCO and SAS softwares.

\section{RESULTS}

\section{TEA Concentrations, Export, and Proportions}

The atmospheric deposition of all the TEAs decreased from south to north (Figure 3A, B), but the 


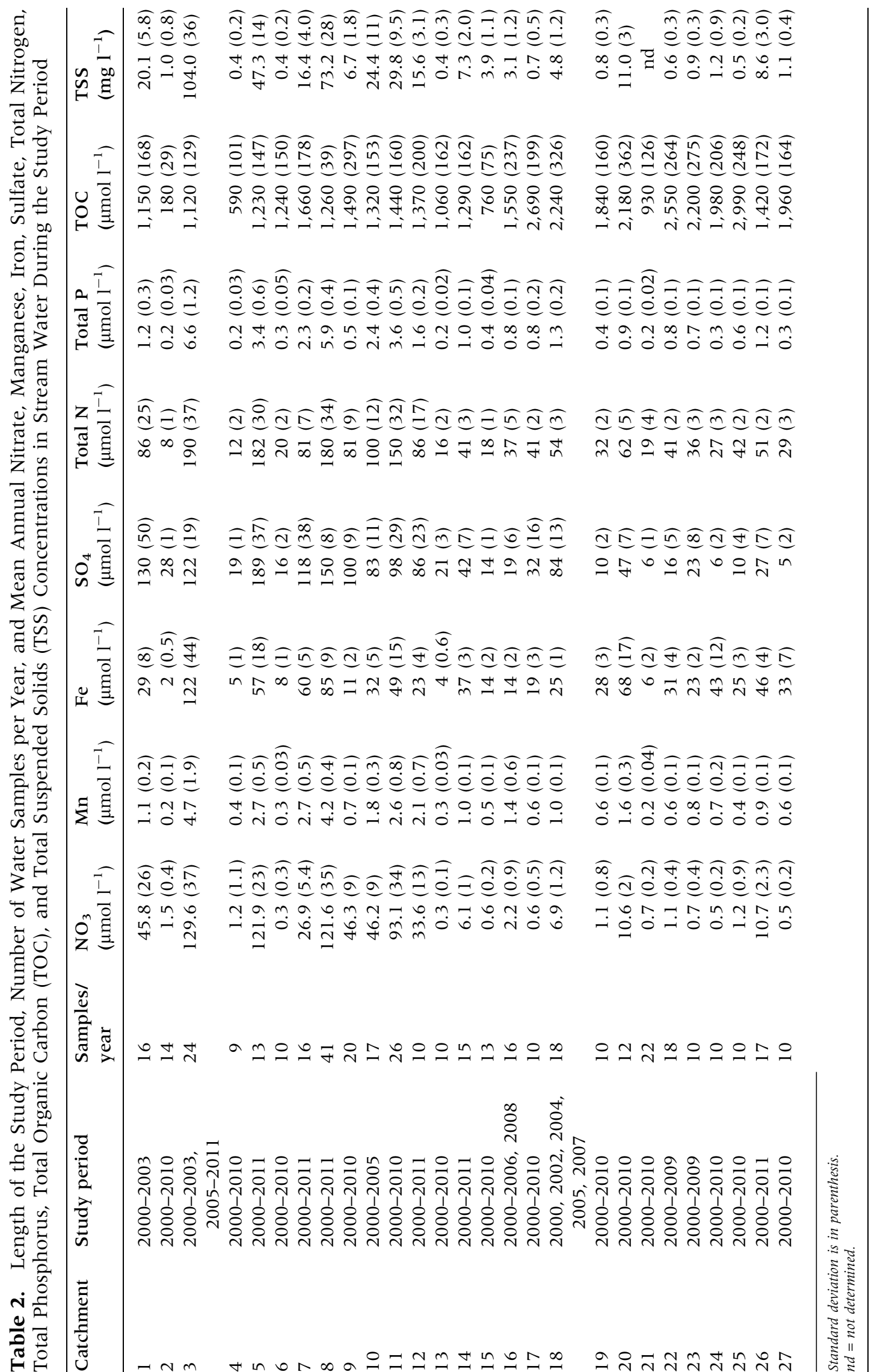


A
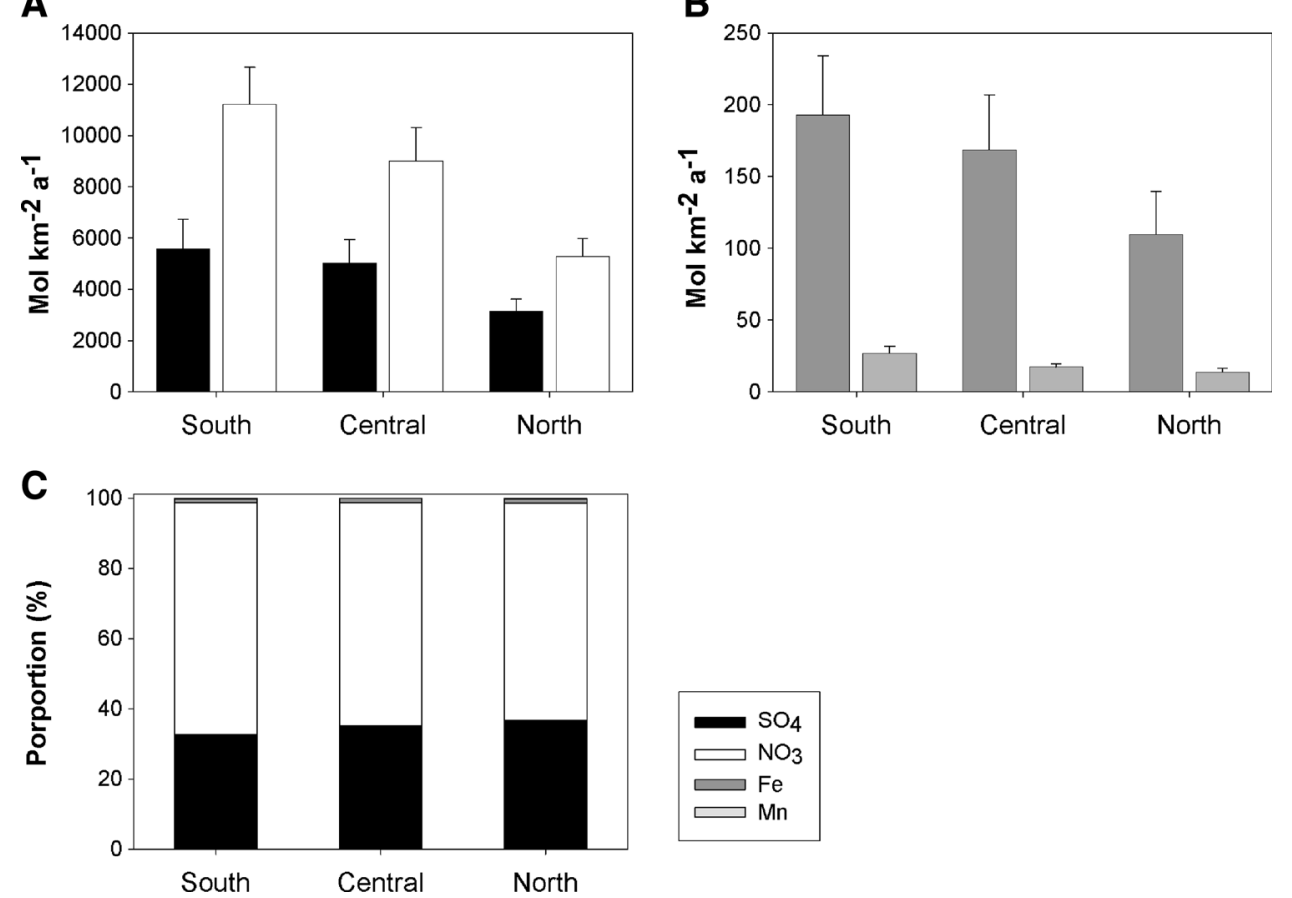

Figure 3. Mean $(+\mathrm{SD})$ annual atmospheric $\mathrm{SO}_{4}$ and $\mathrm{NO}_{3}(\mathbf{A})$, and $\mathrm{Fe}$ and Mn deposition (B) and the molar ratio of $\mathrm{SO}_{4}$, $\mathrm{NO}_{3}, \mathrm{Fe}$, and $\mathrm{Mn}$ of the total TEA deposition (C) in southern, central, and northern Finland during the years 2000-2011. molar share of TEAs was similar in all the three sites, $\mathrm{NO}_{3}$ and $\mathrm{SO}_{4}$ being the dominant TEAs (Figure $3 \mathrm{C}$ ). In runoff, the variation in the average annual concentrations of $\mathrm{NO}_{3}$ (range 0.3$\left.130 \mu \mathrm{mol} \mathrm{l}^{-1}\right)$, Mn $\left(0.2-4.7 \mu \mathrm{mol} \mathrm{l}^{-1}\right)$, Fe $(2-$ $\left.122 \mu \mathrm{mol} \mathrm{l}^{-1}\right)$, and $\mathrm{SO}_{4}\left(5-189 \mu \mathrm{mol} \mathrm{l}^{-1}\right)$, among the catchments was large (Table 2). The concentration of $\mathrm{NO}_{3}$ increased with Field \% $\left(\mathrm{NO}_{3}=3.1\right.$ Field $\%+5.5, r^{2}=0.89$ ), with only two "nonagricultural" catchments (1 Yli-Knuuttila and 9 Teeressuonoja) having a high $\mathrm{NO}_{3}$ concentration. The concentration of Fe also correlated positively with Field\%, although less than $\mathrm{NO}_{3}(\mathrm{Fe}=1.7$ Field $\left.\%+22, r^{2}=0.57\right)$. In agricultural catchments, Fe and Mn concentrations correlated positively with TSS $(r=0.93, P<0.01)$, indicating that Fe and Mn were mainly in a particulate form. The concentrations of $\mathrm{SO}_{4}$ increased with Field $\%$ and decreased with Peat $\%$. The concentrations of $\mathrm{SO}_{4}$ correlated best with total $\mathrm{N}(r=0.89, P<0.01)$ and $\mathrm{NO}_{3}$ $(r=0.87, P<0.01)$ out of the determined water quality variables. Catchment 18 (Kesselinpuro) had a high $\mathrm{SO}_{4}$ concentration despite a negligible Field \%, which is probably related to the presence of black schists in the bedrock of this catchment.

The variation in the TEA export among the catchments (Figure 4) was highest for $\mathrm{NO}_{3}$ (range 50-40700 mol km ${ }^{-2} \mathrm{a}^{-1}$, the maximum export was 814 times higher than the minimum export) followed by Fe $\left(850-44,300 \mathrm{~mol} \mathrm{~km}^{-2} \mathrm{a}^{-1}\right.$, max/ $\min =52 \times), \quad M n \quad\left(50-1470 \mathrm{~mol} \mathrm{~km}{ }^{-2} \mathrm{a}^{-1}, \max /\right.$ $\min =29 \times)$, and $\mathrm{SO}_{4}\left(1790-42260 \mathrm{~mol} \mathrm{~km}^{-2} \mathrm{a}^{-1}\right.$, $\max / \min =24 \times)$. The relative distribution of the concentrations and exports of TEAs were rather similar (Figure 5). $\mathrm{NO}_{3}, \mathrm{Mn}$, and $\mathrm{SO}_{4}$ exports were highest in the agricultural catchments (Figure 4). Fe exports were higher in agricultural and peatland-dominated catchments than in forest-dominated catchments. The exports of $\mathrm{Mn}, \mathrm{Fe}$, and $\mathrm{SO}_{4}$ exceeded their inputs from atmospheric deposition (Figures 3,4$)$. In contrast, $\mathrm{NO}_{3}$ exports from forestand peatland-dominated catchments were smaller than inputs from the deposition. The molar distribution of TEAs in runoff differed greatly from that in atmospheric deposition; $\mathrm{SO}_{4}$ and $\mathrm{Fe}$ were the dominant TEAs in runoff, the proportion of $\mathrm{Mn}$ being only $0.5-4 \%$ (Figure 5 ). The proportion of $\mathrm{NO}_{3}$ was highly variable among catchments $(1-46 \%)$. Atmospheric deposition was a poor predictor for $\mathrm{Fe}\left(r^{2}=0.002, \quad P=0.316\right)$ and $\mathrm{SO}_{4}$ $\left(r^{2}=0.001, P=0.321\right)$ export and explained only $24 \%$ and $27 \%$ of the variation in $\mathrm{NO}_{3}$ and $\mathrm{Mn}$ exports, respectively $(P<0.01)$.

\section{Effect of Land Cover on TEA Export}

According to PCA, land cover explained $76 \%$ of the variation in TEA export $(F=13.0, P=0.002)$. The first two axes represented 68 and $7 \%$ of the total variation. The PCA ordination indicated that the export of TEAs increased with Field\% (Figure 6A). The export of $\mathrm{SO}_{4}$ was also positively correlated with Built-up\%. The increase in Forest $\%$ decreased 

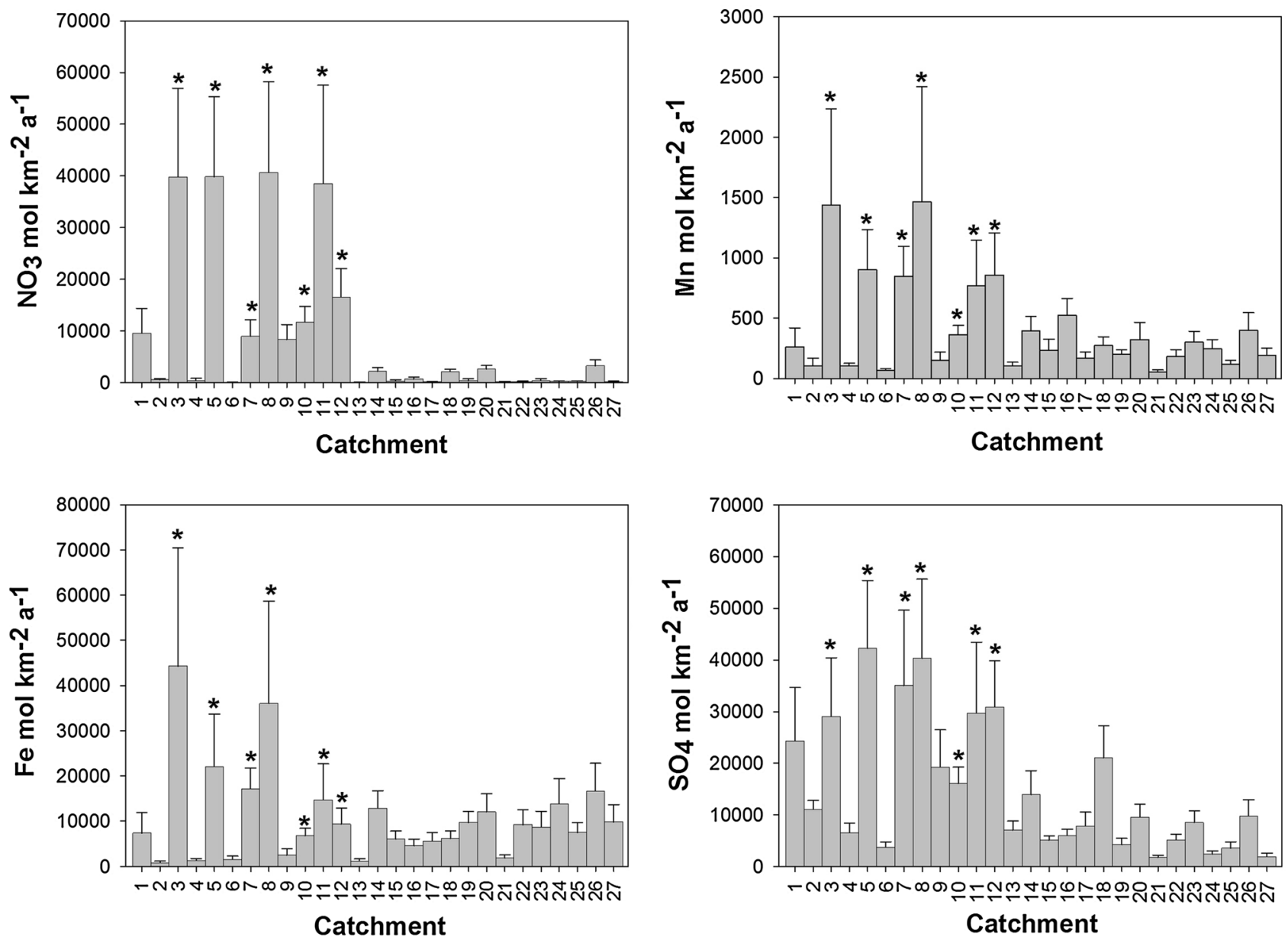

Figure 4. Mean (+SD) annual TEA export from the catchments during the years 2000-2011. The catchments in which the proportion of fields exceeds $10 \%$ are marked with *.

the export of $\mathrm{Fe}$, and an increase in Peat \% decreased the export of $\mathrm{SO}_{4}$ (Figure 6A).

Land cover explained $76 \%$ of the variation in TEA proportions $(F=13.3, P=0.002)$. The PCA ordination indicated that the proportion of $\mathrm{NO}_{3}$ flux increases with an increasing Field \% and Builtup $\%$ (Figure 6B). Peat $\%$ increased the proportions of $\mathrm{Mn}$ and $\mathrm{Fe}$ and resulted in a low proportion of $\mathrm{SO}_{4}$. The proportion of $\mathrm{SO}_{4}$ increased with Forest $\%$.

Multiple regression analysis showed that out of the land-use classes, Field $\%$ and Peat $\%$ best described the TEA export. Together, they explained as much as $93,80,75$, and $67 \%$ of the $\mathrm{NO}_{3}, \mathrm{Mn}, \mathrm{Fe}$, and $\mathrm{SO}_{4}$ export, respectively, when all the catchments were included in the analysis (Figure 7). The coefficients of $\mathrm{SO}_{4}$ and $\mathrm{NO}_{3}$ for Peat $\%$ were negative. The model validation gave similar results. The models for the 14 catchments predicted $93,86,76$, and $76 \%$ of the $\mathrm{NO}_{3}, \mathrm{Mn}, \mathrm{Fe}$, and $\mathrm{SO}_{4}$ exports for the 13 validation catchments, respectively. The exports estimated from the regression models show that the increase in Field\% enhances the export of all TEAs (Figure 8A), but that the proportion of $\mathrm{SO}_{4}$ in the TEA export decreases (Figure 8C). On the other hand, an increase in Peat $\%$ decreases for $\mathrm{NO}_{3}$ and $\mathrm{SO}_{4}$ exports (Figure $8 \mathrm{~B}$ ), Fe being the major TEA from peaty catchments (Figure $8 \mathrm{D}$ ).

\section{Discussion}

\section{Deposition and TEA Export}

Our study showed that the export and molar ratios of TEAs in northern European boreal catchments are predominantly a function of land cover and catchment processes, rather than atmospheric deposition (Figure 7). This is also the case for the export of $\mathrm{NO}_{3}$, although in boreal forest- and peatland-dominated catchments, atmospheric deposition is the major $\mathrm{N}$ source, larger than $\mathrm{N}$ fertilization (Kortelainen and others 1997) and 


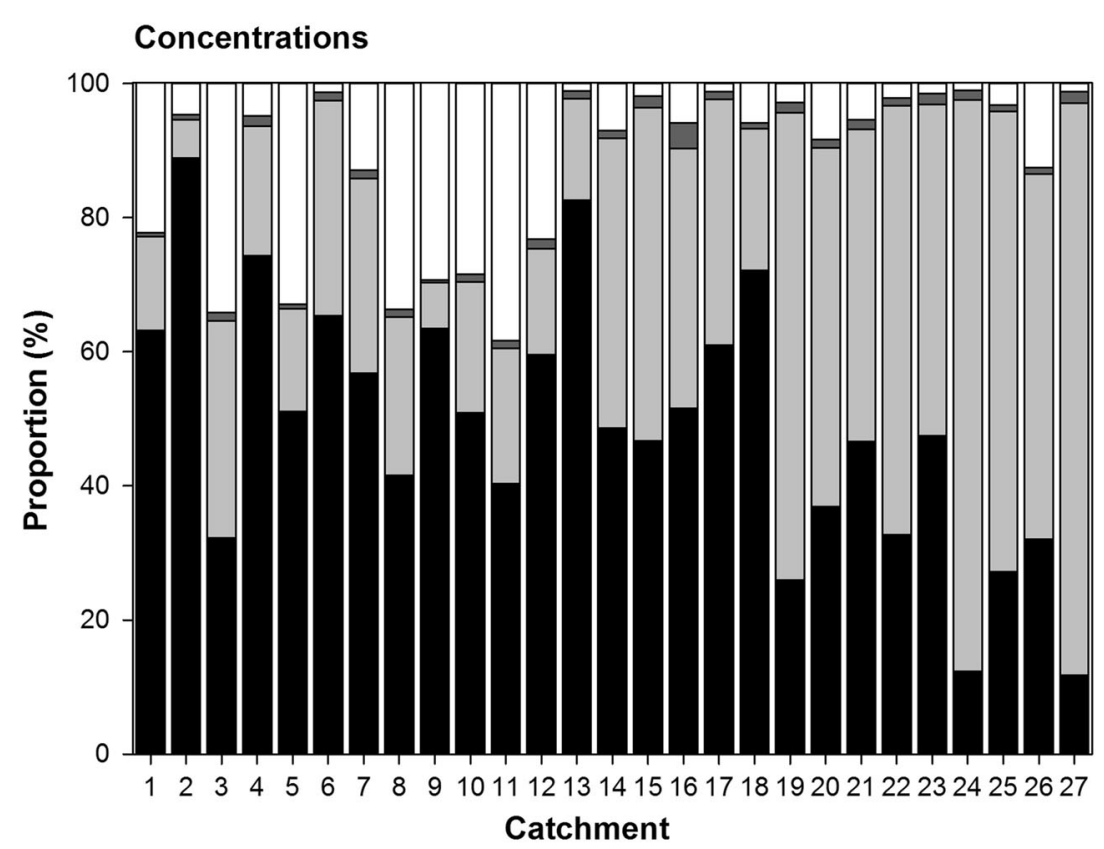

Figure 5. Proportion of $\mathrm{SO}_{4}, \mathrm{NO}_{3}, \mathrm{Fe}$, and $\mathrm{Mn}$ as a percentage of the TEA concentrations and exports.

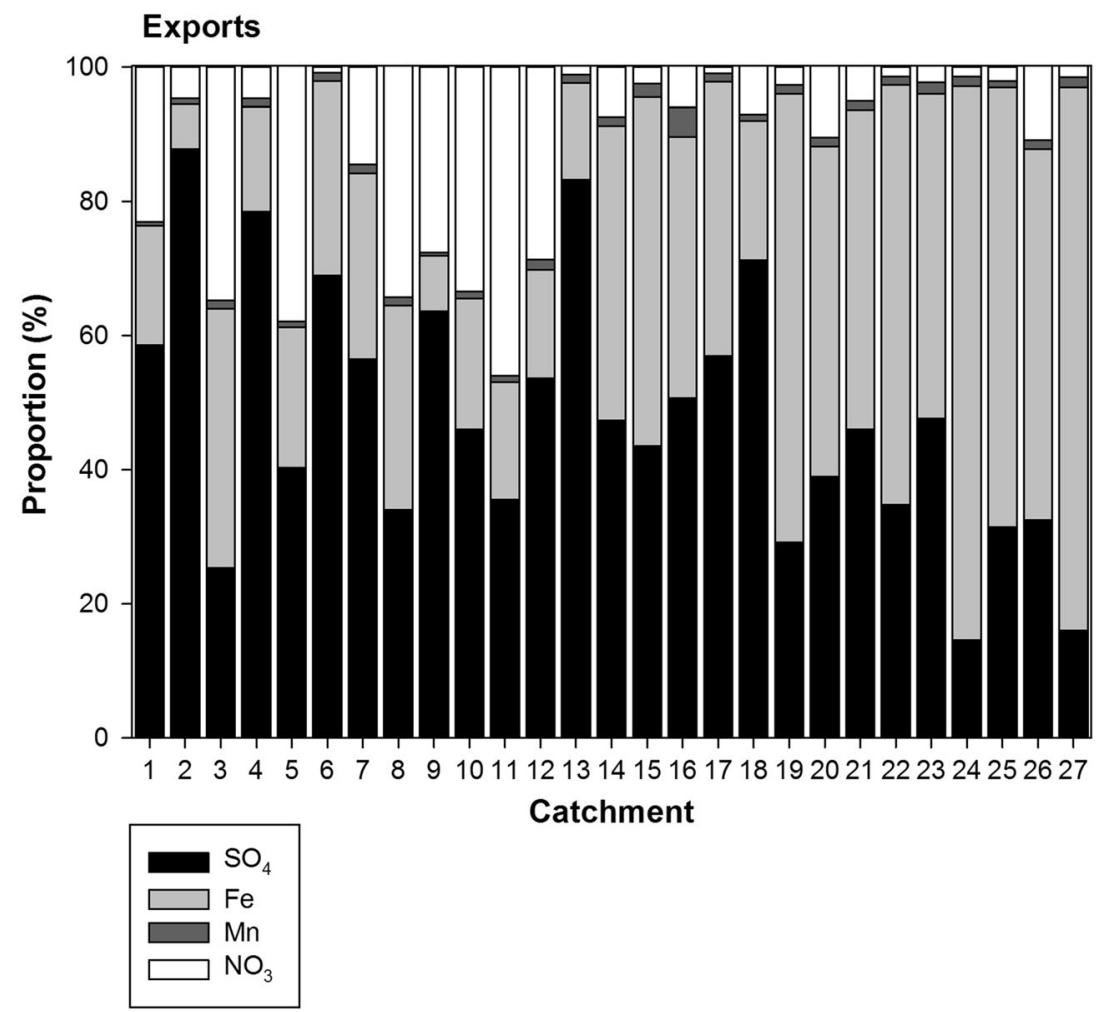

$\mathrm{N}$-fixation (DeLuca and others 2002). The deposition of $\mathrm{NO}_{3}$ and $\mathrm{SO}_{4}$ in Finland (5,3001 1,200 mol km ${ }^{-2} \mathrm{a}^{-1} \mathrm{NO}_{3}, 3,100-5,600 \mathrm{~mol} \mathrm{~km}^{-}$ $2 \mathrm{a}^{-1} \mathrm{SO}_{4}$ ) is small, compared to central and southern Europe $\left(43,000-135,000 \mathrm{~mol} \mathrm{~km}{ }^{-2} \mathrm{a}^{-1}\right.$ $\mathrm{NO}_{3}, 25,000-87,000 \mathrm{~mol} \mathrm{~km}{ }^{-2} \mathrm{a}^{-1} \mathrm{SO}_{4}$ ) (Lorenz and others 2008). In areas of higher deposition,
$\mathrm{NO}_{3}$ and $\mathrm{SO}_{4}$ exports are presumably more closely linked to atmospheric deposition (Dise and Wright 1995; Gundersen and others 2006; Evans and others 2008). Despite the fact that Finland is a long country and the deposition decreases from south to north, the molar ratio of TEAs in the deposition was similar in both southern and northern Finland. 
A

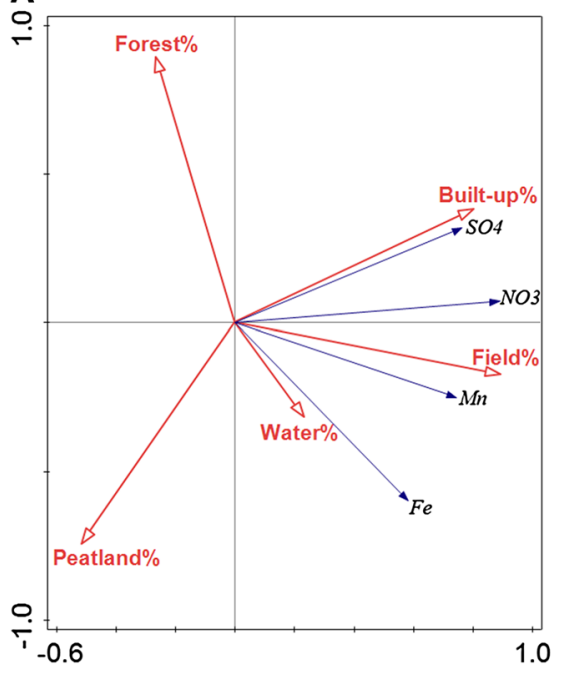

B

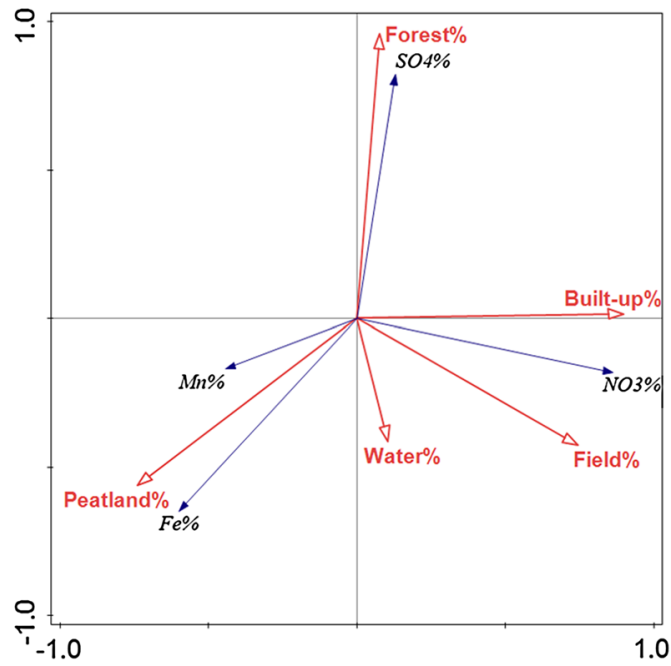

Figure 6. Principal component analysis ordination diagrams showing the main patterns of the variation of TEA exports $(\mathbf{A})$ and molar ratios $(\mathbf{B})$ in relation to the land use.
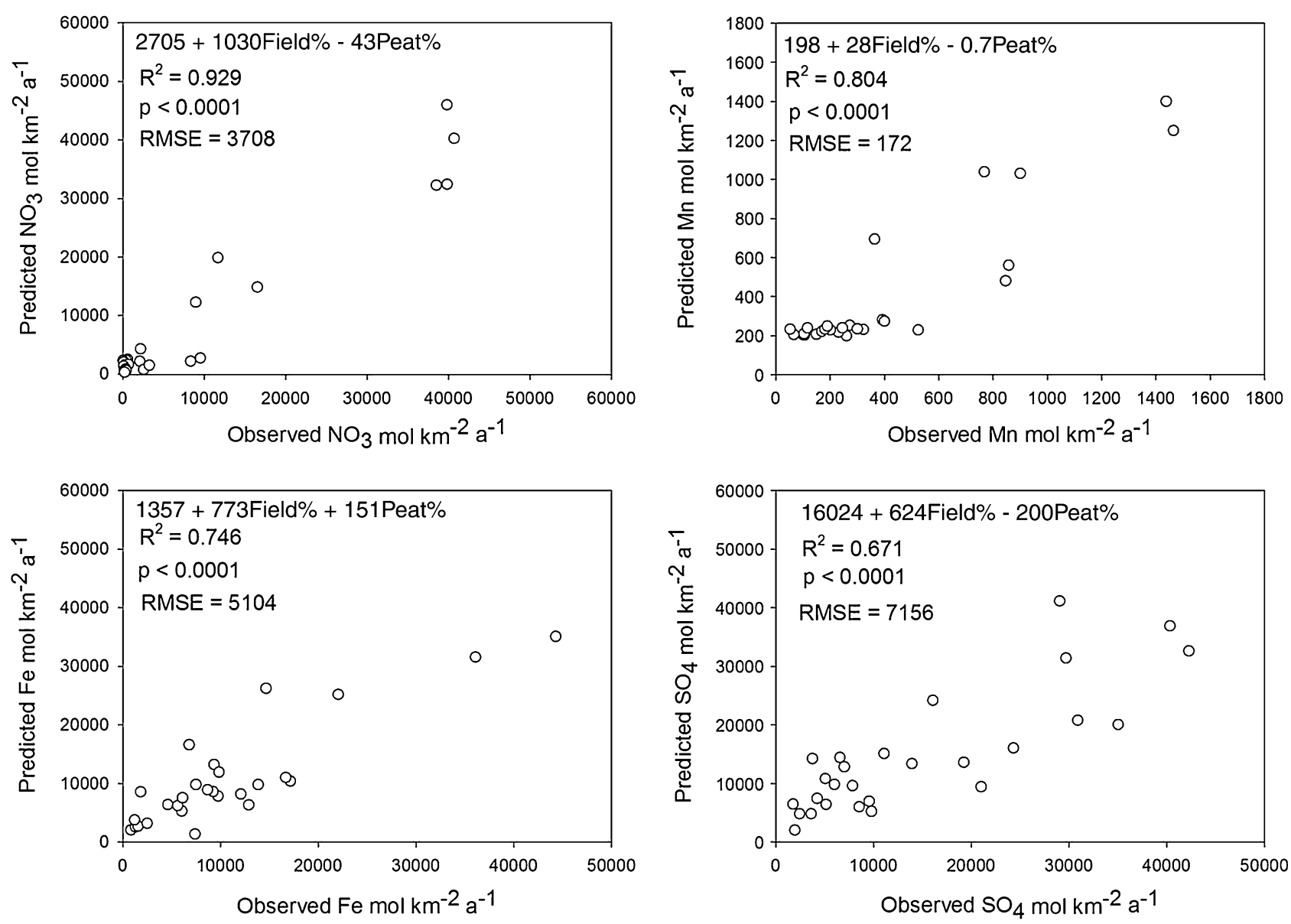

Figure 7. Regression models for estimating TEA export and the observed and predicted $\mathrm{NO}_{3}, \mathrm{Mn}, \mathrm{Fe}$, and $\mathrm{SO}_{4}$ exports.

\section{Agricultural Land and TEA Export}

Fields produced the highest TEA export (Figure 4), the high molar share of $\mathrm{NO}_{3}$ giving field runoff an identifiable signature (Figures 5, 6B). Several factors affect the large TEA export from fields. Agri- cultural lands are fertilized and tend to locate on clayey soils that are sensitive to erosion. The soils have high concentrations of $\mathrm{Mn}$ and Fe (Sippola 1974) and are well drained by ditches and subsurface-drains. The surface is also tilled and often lacks 
vegetation during high run-off periods in the spring and autumn. Soil erosion was presumably the major source of $\mathrm{Mn}$ and $\mathrm{Fe}$, as suggested by their close correlation with TSS, whereas $\mathrm{NO}_{3}$ and $\mathrm{SO}_{4}$ probably mainly originated from fertilizers, organic matter degradation, and atmospheric deposition (Vuorenmaa and others 2002; Mattsson and others 2007; Ekholm and Lehtoranta 2012). Annually about $650,000-850,000 \mathrm{~mol} \mathrm{~N} \mathrm{~km}{ }^{-2}$ and $47,000-$ $62,000 \mathrm{~mol} \mathrm{~S} \mathrm{~km} \mathrm{k}^{-2}$ are added with fertilizers to agricultural fields in Finland (Salo and others 2007; Yli-Halla and others 2011). Both $\mathrm{NO}_{3}$ and $\mathrm{SO}_{4}$ concentrations have also been shown to correlate positively with Field\% in previous studies (for example, Korkman 1973; Ekholm and others 2000; Strayer and others 2003; Williams and others 2005; Mattsson and others 2005, 2007).

\section{Forests and TEA Export}

Forests exported TEAs much less than fields (Figure 4). Boreal forests are $\mathrm{N}$-limited and the losses of $\mathrm{NO}_{3}$ are negligible (Tamm 1991; MacDonald and others 2002), if extensive forestry operations have not been carried out (Palviainen and others 2014). In podzolic forest soils, Mn and Fe are enriched and retained in the B-horizon as oxides and hydroxides (Lundström and others 2000). $\mathrm{SO}_{4}$, in turn, is adsorbed onto the surfaces of aluminum and iron oxides and hydroxides in mineral soils (Gustavsson and Jacks 1993; Piirainen and others 2002). TEA concentrations and exports in forest-dominated catchments were of the same order of magnitude as previously reported for boreal forested catchments (Nilsson 1985; Tarvainen and others 1997; Kortelainen and Saukkonen 1998; Mattsson and others 2003; Finér and others 2004; Kortelainen and others 2006; Björkvald and others 2008). Forests leached proportionally more $\mathrm{SO}_{4}$ than peatlands. Coniferous trees are efficient at intercepting $\mathrm{SO}_{4}$ dry deposition and, therefore, throughfall in the forest contains more $\mathrm{SO}_{4}$ than bulk deposition (Piirainen and others 2004). The export of $\mathrm{Mn}, \mathrm{Fe}$, and $\mathrm{SO}_{4}$ in runoff exceeded the atmospheric input which is in line with other mass balance studies from forested catchments (Navrátil and others 2007; Watmough and others 2005, 2007; Björkvald and others 2009).

\section{Peatlands and TEA Export}

The water-logged peatlands produced low exports of $\mathrm{NO}_{3}$ and $\mathrm{SO}_{4}$, but high exports of Fe. Retention of $\mathrm{NO}_{3}$ is usually high in northern peatlands and
$\mathrm{NO}_{3}$ concentrations in peatland waters are low (Gorham and others 1984; Lepistö and others 2001). Nitrogen mineralization and nitrification rates are lower in peatlands than in mineral forest soils (Devito and others 1999), and a high water table promotes anaerobic conditions in peatlands, which can result in increased denitrification and consequently low $\mathrm{NO}_{3}$ export (Martikainen and others 1993; Regina and others 1996). The increase in Peat\% decreased the export of $\mathrm{SO}_{4}$. Unlike wellaerated forest soils, anaerobic peat layers may immobilize $\mathrm{S}$ in the form of organic $\mathrm{C}$ bonded $\mathrm{S}, \mathrm{Fe}$ monosulfide $(\mathrm{FeS})$, and pyrite $\left(\mathrm{FeS}_{2}\right)$ by means of dissimilatory bacterial $\mathrm{SO}_{4}$ reduction (Mörth and others 1999; Eimers and others 2004; Novák and others 2005). Significant negative correlation between Peat $\%$ and $\mathrm{NO}_{3}$ and $\mathrm{SO}_{4}$ concentrations have also been observed in other boreal headwater and river basins (Kortelainen and Saukkonen 1995; Eimers and others 2004; Finér and others 2004; Mattsson and others 2005, 2007; Kortelainen and others 2006; Björkvald and others 2009; Pester and others 2012). Fields produced the highest export of $\mathrm{Fe}$, but it is evident that peat environments are also a major source of terrestrial $\mathrm{Fe}$ in surface waters, as highlighted by previous studies (Heikkinen 1994; Kortelainen and Saukkonen 1998; Dillon and Molot 1997; Kortelainen and others 2006). Fe export from peatland-dominated catchments correlated with TOC export $(r=0.599, P=0.007)$. The biogeochemical cycles of TOC and Fe are strongly interlinked (for example, Shapiro 1966; Knorr 2013) and a major part of Fe is exported as organic Fe-rich colloids (Kortelainen and Saukkonen 1998; Björkvald and others 2008). Likewise, the mobilization of $\mathrm{Mn}$ is strongly controlled by dissolved organic matter (Tarvainen and others 1997; Graham and others 2002), which was reflected in our data as an increased proportion of $\mathrm{Mn}$ in the TEA export with increasing Peat $\%$.

In addition to the above land-cover classes, other factors, such as bedrock, soil texture and fertility, weathering, the decomposition degree of peat, catchment slope, and land management practices, probably cause a variation in TEA export (Urban and others 1990; Ekholm and others 2000; Mattsson and others 2003; Finér and others 2004; Herranen 2009; Palviainen and others 2014). For example, a high $\mathrm{NO}_{3}$ export from forested Catchments 1 (Yli-Knuuttila) and 9 (Teeressuonoja) may be due to the abundance of fertile Oxalis-Myrtillus forest site types (Cajander 1949) in these catchments (Kortelainen and others 2006). Furthermore, geology and soil properties largely determine the land use. Generally, most fertile soils are converted 

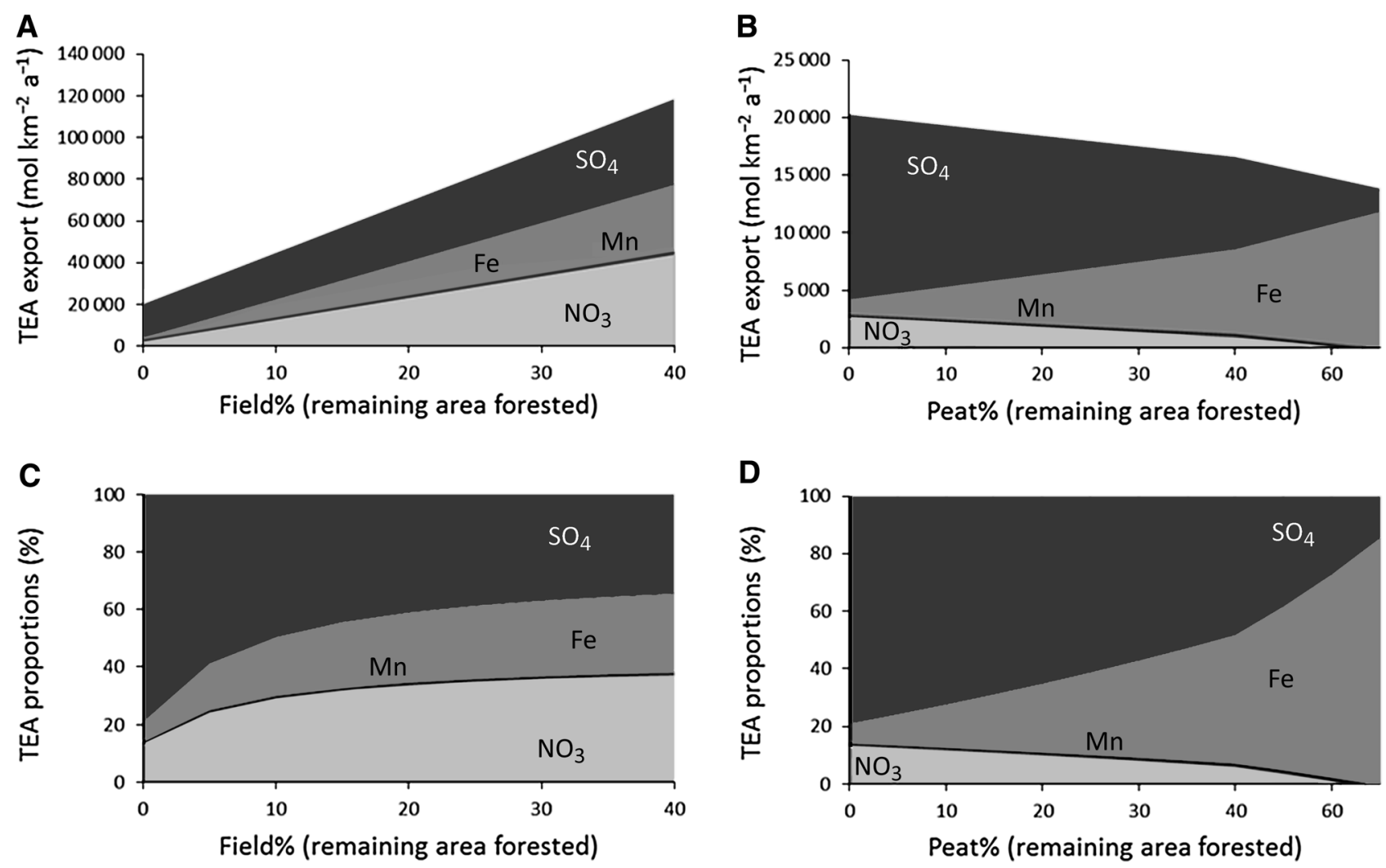

Figure 8. Proportions and exports of TEAs as estimated from regression models in Figure 7. Export of TEAs as a function of field percentage $(\mathbf{A})$ and peat percentage $(\mathbf{B})$; proportions of TEAs as a function of field percentage $(\mathbf{C})$ and peat percentage $(\mathbf{D})$.

to fields and, therefore, runoff chemistry is the combination of soil development and land use.

\section{Significance of TEAs}

We have shown a great variability of the export of TEAs from different land-cover classes in the boreal zone, but the behavior and retention of TEAs and their significance may vary in the recipient system, depending on the morphology, retention time, and trophic status of the system (Rysgaard and others 2001; Thomsen and others 2004; Maerki and others 2009; Finlay and others 2013). The physical and chemical forms of $\mathrm{NO}_{3}, \mathrm{Mn}, \mathrm{Fe}$, and $\mathrm{SO}_{4}$ determine whether these substances can actually be used as TEAs in anaerobic mineralization processes downstream. In our study, $\mathrm{NO}_{3}$ and $\mathrm{SO}_{4}$ are probably predominantly in a dissolved form, readily to be used as TEAs, whereas Mn and Fe were measured as total concentrations, which do not reveal their direct availability as TEAs in clay particles (Kostka and others 1999, 2002) or in organic complexes (Allard and others 2004; Gaffney and others 2008; Pédrot and others 2011). In agricultural and peat- land catchments, Mn and Fe correlated with TSS and TOC, respectively, indicating that $\mathrm{Mn}$ and $\mathrm{Fe}$ were in a form that may settle on the bottom. In contrast, dissolved $\mathrm{NO}_{3}$ and $\mathrm{SO}_{4}$ are more likely to be transported through the system with less contact to anaerobic layers. Yet, the export of organic $\mathrm{N}$ and $\mathrm{S}$ may form a significant source for TEAs after mineralization and oxidation to $\mathrm{NO}_{3}$ and $\mathrm{SO}_{4}$. TEAs also affect mineralization and material fluxes in the catchment, but their importance is pronounced in aquatic systems, where anaerobic mineralization plays an important role in sediments. Climate change scenarios predict increasing precipitation for northern Europe and an increasing frequency of heavy rainfalls over land areas (Denman and 2007), which can be supposed to result in an increased variation of redox conditions. Several recent studies suggest that climate change may lead to increased TEA export from temperate and boreal catchments, due to changes in precipitation, runoff regimes, and soil redox conditions (Heal 2001; Clark and others 2005; Kritzberg and Ekström 2012; Knorr 2013; Sarkkola and others 2013). 


\section{ConClusions}

Our study demonstrates that both concentrations and exports of TEAs are specific for each land-cover class (Figure 8). On the basis of our findings, changes in the export of TEAs may emerge through an increase in Field\%, whereas afforestation may decrease TEA export, but increase the relative proportion of $\mathrm{SO}_{4}$. Clear-cutting, in turn, may enhance $\mathrm{NO}_{3}$ fluxes (Palviainen and others 2014). Terrestrial ecosystems and their utilization create different premises for the anaerobic mineralization pathways. These pathways, in turn, may have fundamental effects on the system functions through the feedbacks on the retention ability of nutrients and harmful substances and the formation of greenhouse gas fluxes in the aquatic ecosystems. The acknowledgement of the concept of coupled biogeochemical cycles might enhance an understanding of not only the outcome of a diffuse load in a body of water, but also of the load generating factors in the catchments. This highlights the need for considering the influences of landscape characteristics on the export of TEAs-in addition to the load of organic $\mathrm{C}$ and nutrients-in predicting long-term changes in the biogeochemistry of terrestrial and aquatic systems.

\section{ACKNOWLEDGMENTS}

This study was part of the TEAQUILA project (Decision Number 263476) supported by the AKVA programme of the Academy of Finland. We thank Saara Kirjalainen for her assistance with land-cover databases and Antti Räike for preparing the map.

\section{OPEN ACCESS}

This article is distributed under the terms of the Creative Commons Attribution License which permits any use, distribution, and reproduction in any medium, provided the original author(s) and the source are credited.

\section{REFERENCES}

Allard T, Menguy N, Salomon J, Galligaro T, Weber T, Calas G, Benedetti MF. 2004. Revealing forms of iron in river-borne material from major tropical rivers of the Amazon Basin (Brazil). Geochim Cosmochim Acta 68:3079-94.

Barco J, Gunawan S, Hogue TS. 2013. Seasonal controls on stream chemical export across diverse coastal watersheds in the USA. Hydrol Process 27:1440-53.

Beal EJ, House CH, Orphan VJ. 2009. Manganese- and iron dependent marine methane oxidation. Science 325:184-7.

Björkvald L, Buffam I, Laudon H, Mörth C-M. 2008. Hydrogeochemistry of Fe and $\mathrm{Mn}$ in small boreal streams: the role of seasonality, landscape type and scale. Geochim Cosmochim Acta 72:2789-804.

Björkvald L, Giesler R, Laudon H, Humborg C, Mörth C-M. 2009. Landscape variations in stream water $\mathrm{SO}_{4}$ and $\delta^{34} \mathrm{SSO}_{4}$ in a boreal stream network. Geochim Cosmochim Acta 73:4648-60.

Bridgham SD, Cadillo-Quiroz H, Keller JK, Zhuang Q. 2013. Methane emissions from wetlands: biogeochemical, microbial, and modeling perspectives from local to global scales. Glob Change Biol 19:1325-46.

Burgin AJ, Yang WH, Hamilton SK, Silver WL. 2011. Beyond carbon and nitrogen: how the microbial energy economy couples elemental cycles in diverse ecosystems. Front Ecol Environ 9:44-52.

Cai Z, Zhang J, Zhu T, Cheng Y. 2012. Stimulation of NO and $\mathrm{N}_{2} \mathrm{O}$ emissions from soils by $\mathrm{SO}_{2}$ deposition. Glob Change Biol 18:2280-91.

Cajander AK. 1949. Forest types and their significance. Acta For Fenn 56:1-71.

Clark JM, Chapman PJ, Adamson JK, Lane SN. 2005. Influence of drought-induced acidification on the mobility of dissolved organic carbon in peat soils. Glob Change Biol 11:791-809.

Conrad R. 1996. Soil microorganisms as controllers of atmospheric trace gases $\left(\mathrm{H}_{2}, \mathrm{CO}, \mathrm{CH}_{4}, \mathrm{OCS}, \mathrm{N}_{2} \mathrm{O}\right.$, and $\left.\mathrm{NO}\right)$. Microb Reviews 60:609-40.

Curtis CJ, Evans CD, Helliwell RC, Monteith DT. 2005. Nitrate leaching as a confounding factor in chemical recovery from acidification in UK upland waters. Environ Pollut 137:73-82.

Davidson EA, Seitzinger S. 2006. The enigma of progress in denitrification research. Ecol Appl 16:2057-63.

DeLuca TH, Zackrisson O, Nilsson M-C, Sellstedt A. 2002. Quantifying nitrogen-fixation in feather moss carpets of boreal forests. Nature 419:917-20.

Denman KL et al. 2007. Couplings between changes in the climate system and biogeochemistry in climate change 2007: the physical science basis. In: Solomon $\mathrm{S}$ et al., Eds. Contribution of working group 1 to the fourth assessment report of the intergovernmental panel on climate change. Cambridge: Cambridge University Press. p 499-587.

Devito KJ, Westbrook CJ, Schiff SR. 1999. Nitrogen mineralization and nitrification in upland and peatland forest soils in two Canadian Shield catchments. Can J For Res 29:1793-804.

Dillon PJ, Molot LA. 1997. Effect of landscape form on export of dissolved organic carbon, iron, and phosphorus from forested stream catchments. Water Resour Res 33:2591-6000.

Dise NB, Verry ES. 2001. Suppression of peatland methane emission by cumulative sulfate deposition in simulated acid rain. Biogeochemistry 53:143-60.

Dise NB, Wright RF. 1995. Nitrogen leaching from European forests in relation to nitrogen deposition. For Ecol Manag $71: 153-61$

Eimers MC, Dillon PJ, Schiff SL. 2004. A S-isotope approach to determine the relative contribution of redox processes to net $\mathrm{SO}_{4}$ export from upland, and wetland-dominated catchments. Geochim Cosmochim Acta 68:3665-74.

Ekholm P, Lehtoranta J. 2012. Does control of soil erosion inhibit aquatic eutrophication? J Environ Manag 93:140-6.

Ekholm P, Kallio K, Salo S, Pietiläinen O-P, Rekolainen S, Laine Y, Joukola M. 2000. Relationship between catchment catchment characteristics and nutrient concentrations in an agricultural river system. Water Res 34:3709-16. 
EMEP. 2001. EMEP/CCC. Manual for sampling and chemical analysis. Revised November 2001. EMEP/CCC-Report 1/95. Kjeller: Norwegian Institute for Air Research. http://www. nilu.no/projects/ccc/manual/index.html. Accessed June 2014.

Evans CD, Norris D, Ostle N, Grant H, Rowe EC, Curtis CJ, Reynolds B. 2008. Rapid immobilisation and leaching of wetdeposited nitrate in upland organic soils. Environ Pollut 156:636-43.

Finér L, Ahtiainen M, Mannerkoski H, Möttönen V, Piirainen S, Seuna P, Starr M. 1997. Effects of harvesting and scarification on water and nutrient fluxes. A description of catchment and methods, and results from the pretreatment calibration period. Research paper 648. Joensuu: Finnish Forest Research Institute, Joensuu Research Station.

Finér L, Kortelainen P, Mattsson T, Ahtiainen M, Kubin E, Sallantaus T. 2004. Sulphate and base cation concentrations and export in streams from unmanaged forested catchments in Finland. For Ecol Manag 195:115-28.

Finlay JC, Small GE, Sterner RW. 2013. Human influences on nitrogen removal in lakes. Science 342:247-50.

Fuss CB, Driscoll CT, Johnson CE, Petras RJ, Fahey TJ. 2011. Dynamics of oxidized and reduced iron in a northern hardwood forest. Biogeochemistry 104:103-19.

Gaffney JW, White KN, Boult S. 2008. Oxidation state and size of Fe controlled by organic matter in natural waters. Environ Sci Technol 42:3575-81.

Gorham E, Bayley SE, Schindler DW. 1984. Ecological effects of acid deposition upon peatlands: a neglected field in 'acid-rain' research. Can J Aquat Sci 41:1256-68.

Graham MC, Gavin KG, Farmer JG, Kirika A, Britton A. 2002. Processes controlling the retention and release of manganese in the organic-rich catchment of Loch Bradan, SW Scotland. Appl Geochem 17:1061-7.

Gundersen P, Schmidt IK, Raulund-Rasmussen K. 2006. Leaching of nitrate from temperate forests-effects of air pollution and forest management. Environ Rev 14:1-57.

Gustavsson JP, Jacks G. 1993. Sulphur status in some Swedish podzols as influenced by acid deposition and extractable organic carbon. Environ Pollut 81:185-91.

Hall SJ, Silver WL. 2013. Iron oxidation stimulates organic matter decomposition in humid tropical forest soils. Glob Change Biol 19:2804-13.

Heal KV. 2001. Manganese and land-use in upland catchments in Scotland. Sci Total Environ 265:169-79.

Heikkinen K. 1994. Organic matter, iron and nutrient transport and nature of dissolved organic matter in the drainage basin of a boreal humic river in northern Finland. Sci Total Environ 152:81-9.

Henriksen A, Kämäri J, Posch M, Wilander A. 1992. Critical loads of acidity: nordic surface waters. Ambio 21:356-63.

Herranen T. 2009. The sulfur concentration of peat in Finland. Geological Survey of Finland, Peat Researches, Report of Peat Investigation 398.

Holmer M, Storkholm P. 2001. Sulphate reduction and sulphur cycling in lake sediments: a review. Freshw Biol 46:431-51.

Islam FS, Gault AG, Boothman C, Polya DA, Charnock JM, Chatterjee D, Lloyd JR. 2004. Role of metal-reducing bacteria in arsenic release from Bengal delta sediments. Nature 430:68-71.

Kane ES, Chivers MR, Turetsky MR, Treat CC, Petersen DG, Waldrop M, Harden JW, McGuire AD. 2013. Response of anaerobic carbon cycling to water table manipulation in an Alaskan rich fen. Soil Biol Biochem 58:50-60.

Knittel K, Boetius A. 2009. Anaerobic oxidation of methane: progress with an unknown process. Annu Rev Microbiol 63:311-34.

Knorr K-H. 2013. DOC-dynamics in a small headwater catchment as driven by redox fluctuations and hydrological flow paths-are DOC exports mediated by iron reduction/oxidation? Biogeosciences 10:891-904.

Kopáĉek J, Cosby BJ, Evans CD, Hruška J, Moldan F, Oulehle F, Šantruĉková H, Tahovská K, Wright RF. 2013. Nitrogen, organic carbon and sulphur cycling in terrestrial ecosystems: linking nitrogen saturation to carbon limitation of soil microbial processes. Biogeochemistry 115:33-51.

Korkman J. 1973. Sulphur status of Finnish cultivated soils. J Sci Agric Soc Finl 45:121-215.

Kortelainen P, Saukkonen S. 1995. Organic vs. minerogenic acidity in headwater streams in Finland. Water Air Soil Pollut 85:559-64.

Kortelainen P, Saukkonen S. 1998. Leaching of nutrients, organic carbon and iron from Finnish forestry land. Water Air Soil Pollut 105:239-50.

Kortelainen P, Saukkonen S, Mattsson T. 1997. Leaching of nitrogen from forested catchments in Finland. Glob Biogeochem Cycles 11:627-38.

Kortelainen P, Mattsson T, Finér L, Ahtiainen M, Saukkonen S, Sallantaus T. 2006. Controls on the export of C, N, P and Fe from undisturbed boreal catchments, Finland. Aquat Sci 68:453-68.

Kortelainen P, Rantakari M, Pajunen H, Huttunen JT, Mattsson $\mathrm{T}$, Juutinen S, Larmola T, Alm J, Silvola J, Martikainen PJ. 2013. Carbon evasion/accumulation ratio in boreal lakes is linked to nitrogen. Glob Biogeochem Cycles 27:363-74.

Kostka JE, Wu J, Nealson KH, Stucki JW. 1999. The impact of structural Fe(III) reduction by bacteria on the surface chemistry of smectite clay minerals. Geochim Cosmochim Acta 63:3705-13.

Kostka JE, Dalton DD, Skelton H, Dollhopf S, Stucki JW. 2002. Growth of iron(III)-reducing bacteria on clay minerals as the sole electron acceptor and comparison of growth yields on a variety of oxidized iron forms. Appl Environ Microbiol 68:6256-62.

Kritzberg ES, Ekström SM. 2012. Increasing iron concentrations in surface waters-a factor behind brownification? Biogeosciences 9:1465-78.

Lehtoranta J, Ekholm P, Pitkänen H. 2009. Coastal eutrophication thresholds-a matter of sediment microbial processes. Ambio 38:303-8.

Lepistö A, Kenttämies K, Rekolainen S. 2001. Modeling combined effects of forestry, agriculture and deposition on nitrogen export in a northern river basin in Finland. Ambio 30:338-48.

Lorenz M, Nagel H-D, Granke O, Kraft P. 2008. Critical loads and their exceedances at intensive forest monitoring sites in Europe. Environ Pollut 155:426-35.

Lundström US, van Breemen N, Bain D. 2000. The podzolization process. A review. Geoderma 94:91-107.

MacDonald JA, Dise NB, Matzner E, Armbruster M, Gundersen P, Forsius M. 2002. Nitrogen input together with ecosystem nitrogen enrichment predict nitrate leaching from European forests. Glob Change Biol 8:1028-33. 
Maerki M, Müller B, Dinkel C, Wehrli B. 2009. Mineralization pathways in lake sediments with different oxygen and organic carbon supply. Limnol Oceanogr 54:428-38.

Martikainen PJ, Nykänen H, Crill P, Silvola J. 1993. Effect of a lowered water table on nitrous oxide fluxes from northern peatlands. Nature 366:51-3.

Mattsson T, Finér L, Kortelainen P, Sallantaus T. 2003. Brook water quality and background leaching from unmanaged forested catchments in Finland. Water Air Soil Pollut 147:275-97.

Mattsson T, Kortelainen P, Räike A. 2005. Export of DOM from boreal catchments: impacts of land use cover and climate. Biogeochemistry 76:373-94.

Mattsson T, Kortelainen P, Lepistö A, Räike A. 2007. Organic and minerogenic acidity in Finnish rivers in relation to land use cover. Sci Total Environ 383:183-92.

Mörth C-M, Torssander P, Minoru K, Hultberg H. 1999. Sulfur isotope values in a forested catchment over four years: evidence for oxidation and reduction processes. Biogeochemistry 44:51-71.

Navrátil T, Shanley JB, Skřivan P, Krám P, Mihaljevič M, Drahota P. 2007. Manganese biogeochemistry in a central Czech Republic catchment. Water Air Soil Pollut 186:149-65.

Nilsson SI. 1985. Budgets of aluminium species, iron and manganese in the Lake Gardsjön catchment in SW Sweden. Ecol Bull 37:120-32.

Novák M, Adamová M, Wieder RK, Bottrell SH. 2005. Sulfur mobility in peat. Appl Geochem 20:673-81.

Palviainen M, Finér L, Laurén A, Launiainen S, Piirainen S, Mattsson T, Starr M. 2014. Nitrogen, phosphorus, carbon, and suspended solids loads from forest clear-cutting and site preparation: long-term paired catchment studies from eastern Finland. Ambio 43:218-33.

Pédrot M, Le Boudec A, Davranche M, Dia A, Henin O. 2011. How does organic matter constrain the nature, size and availability of $\mathrm{Fe}$ nanoparticles for biological reduction? J Colloid Interface Sci 359:75-85.

Pester M, Knorr K-H, Friedrich MW, Wagner M, Loy A. 2012. Sulfate-reducing microorganisms in wetlands-fameless actors in carbon cycling and climate change. Front Microbiol 3:1-19.

Piirainen S, Finér L, Starr M. 2002. Deposition and leaching of sulphate and base cations in a mixed boreal forest in eastern Finland. Water Air Soil Pollut 131:185-204.

Piirainen S, Finér L, Mannerkoski H, Starr M. 2004. Effects of forest clear-cutting on the sulphur, phosphorus and base cations fluxes through podzolic soil horizons. Biogeochemistry 69:405-24.

Raghoebarsing AA, Pol A, van de Pas-Schoonen KT, Smolders AJP, Ettwig KF, Rijpstra IC, Schouten S, Damsté JSS, Op den Camp HJM, Jetten MSM, Strous M. 2006. A microbial consortium couples anaerobic methane oxidation to denitrification. Nature 440:918-21.

Regina K, Nykänen H, Silvola J, Martikainen PJ. 1996. Fluxes of nitrous oxide from boreal peatlands as affected by peatland type, water table level and nitrification capacity. Biogeochemistry 35:401-18.

Rekolainen S, Posch M, Kämäri J, Ekholm P. 1991. Evaluation of the accuracy and precision of annual phosphorus load estimates from two agricultural basins in Finland. J Hydrol 128:237-55.

Rysgaard S, Fossing H, Jensen MM. 2001. Organic matter degradation through oxygen respiration, denitrification, and manganese, iron, and sulphate reduction in marine sediments (the Kattegat and Skagerrak). Ophelia 55:77-91.

Salo S, Eskelinen J, Jauhiainen L, Kartio M. 2007. Reduced fertiliser use and changes in cereal grain weight and protein content in Finland in 1990-2005. Agric Food Sci 16:407-20.

Sarkkola S, Nieminen M, Koivusalo H, Laurén A, Kortelainen P, Mattsson T, Palviainen M, Piirainen S, Starr M, Finér L. 2013. Iron concentrations are increasing in surface waters from forested headwater catchments in eastern Finland. Sci Total Environ 463-464:683-9.

Seuna P. 1983. Small basins-a tool in scientific and operational hydrology. Publications of the water Research Institute, Finland, 51. National Board of Waters, Helsinki $61 \mathrm{p}$.

Shapiro J. 1966. The relation to humic color of iron in natural waters. Verh Int Ver Limnol 16:477-484.

Sippola J. 1974. Mineral composition and its relation to texture and to some chemical properties in Finnish subsoils. Ann Agric Fenn 13:169-234.

Smolders AJP, Lamers LPM, Lucassen ECHET, Van der Velde G, Roelofs JGM. 2006. Internal eutrophication: how it works and what to do about it-a review. Chem Ecol 22:93-111.

Smolders AJP, Lucassen ECHET, Bobbink R, Roelofs JGM, Lamers LPM. 2010. How nitrate leaching from agricultural lands provokes phosphate eutrophication in groundwater fed wetlands: the sulphur bridge. Biogeochemistry 98:1-7.

Strayer DL, Beighley RE, Thompson LC, Brooks S, Nilsson C, Pinay G, Naiman RJ. 2003. Effects of land cover on stream ecosystems: roles of empirical models and scaling issues. Ecosystems 6:407-23.

Tamm CO. 1991. Nitrogen in terrestrial ecosystems: questions of productivity, vegetational changes, and ecosystem stability. Ecological Studies 81. Berlin: Springer.

Tarvainen T, Lahermo P, Mannio J. 1997. Sources of trace metals in streams and headwater lakes in Finland. Water Air Soil Pollut 94:1-32.

Thomsen U, Thamdrup B, Stahl DA, Canfield DE. 2004. Pathways of organic carbon oxidation in a deep lacustrine sediment, Lake Michigan. Limnol Oceanogr 49:2046-57.

Urban NR, Gorham E, Underwood JK, Martin FB, Ogden JG. 1990. Geochemical processes controlling concentrations of $\mathrm{Al}$, $\mathrm{Fe}$, and $\mathrm{Mn}$ in Nova Scotia lakes. Limnol Oceanogr 35:1516-34.

Urban NR, Brezonik PL, Baker LA, Sherman LA. 1994. Sulfate reduction and diffusion in sediments of Little Rock Lake, Wisconsin. Limnol Oceanogr 3:797-815.

Vuorenmaa J, Rekolainen S, Lepistö A, Kenttämies K, Kauppila P. 2002. Losses of nitrogen and phosphorus from agricultural and forest areas in Finland during the 1980s and 1990s. Environ Monit Assess 76:213-48.

Wang FY, Chapman PM. 1999. Biological implications of sulphide in sediment-a review focusing on sediment toxicity. Environ Toxicol Chem 18:2526-32.

Watmough SA, Aherne J, Alewell C, Arp P, Bailey S, Clair T, Dillon P, Duchesne L, Eimers C, Fernandez I, Foster N, Larssen T, Miller E, Mitchell M, Page S. 2005. Sulphate, nitrogen and base cation budgets at 21 forested catchments in Canada, the United States and Europe. Environ Monit Assess 109:1-36.

Watmough SA, Eimers MC, Dillon PJ. 2007. Manganese cycling in central Ontario forests: response to soil acidification. Appl Geochem 22:1241-7.

Williams M, Hopkinson C, Rastetter E, Vallino J, Claessens L. 2005. Relationship of land use and stream solute concentrations in 
the Ipswich River basin, northeastern Massachusetts. Water Air Soil Pollut 161:55-74.

Yli-Halla M, Pietola L, Kauppila R. 2011. Retrospect of sulphur fertilization in Finland. In: Hera C, Dumitru M, Schnug E,
Dorneanu A, Haneklaus S, Popescu A, Anton I, Panoiu I, Eds. Proceedings of the 15th world fertilizer congress of the International Scientific Centre for Fertilizers (CIEC), Bucharest. p. 13 